Abstracta Iranica Abstracta Iranica

Revue bibliographique pour le domaine irano-aryen

Volume 24 | 2003

Comptes rendus des publications de 2001

\title{
« Berahne dar romān ». Kelk, nº 124, (1380/2001), pp. 34-35. [Nu dans le roman]
}

\section{Christophe Balaÿ}

\section{(2) OpenEdition}

1 Journals

\section{Édition électronique}

URL : http://journals.openedition.org/abstractairanica/34823

DOI : 10.4000/abstractairanica.34823

ISSN : 1961-960X

Éditeur :

CNRS (UMR 7528 Mondes iraniens et indiens), Éditions de l'IFRI

\section{Édition imprimée}

Date de publication : 15 mai 2003

ISSN : 0240-8910

\section{Référence électronique}

Christophe Balaÿ, « «Berahne dar romān ». Kelk, nº 124, (1380/2001),

pp. 34-35. [Nu dans le roman] », Abstracta Iranica [En ligne], Volume $24 \mid 2003$, document 288, mis en ligne le 05 janvier 2010, consulté le 25 septembre 2020. URL : http://journals.openedition.org/ abstractairanica/34823 ; DOI : https://doi.org/10.4000/abstractairanica.34823

Ce document a été généré automatiquement le 25 septembre 2020.

Tous droits réservés 


\section{« Berahne dar romān ». Kelk, nº 124, (1380/2001), pp. 34-35. [Nu dans le roman]}

\section{Christophe Balaÿ}

Petite note de Leylā Șādeqī sur le dernier roman de Moḥammad Moḥammad-'Alī Berahne dar bād («Nu dans le vent », Téhéran, 2000) du point de vue de sa structure narrative «stratifiée » et de la langue du récit qui est d'une grande variété. De toute évidence, l'intertextualité très en vogue dans le roman persan de cette dernière décennie, étonne et interroge.

INDEX

Thèmes : 11.1.2. Littérature persane moderne

\section{AUTEURS}

CHRISTOPHE BALA ̈̈

IFRI/INALCO - Téhéran/Paris 